\section{Activity in rainbow trout (Salmo gairdneri) as a function of acclimation and thermal} environment

\author{
LAWRENCE H. FRANK and MERLE E. MEYER \\ Western Washington State College, Bellingham, Wash. 98225
}

The activity of rainbow trout (Salmo gairdneri) acclimated at $12^{\circ} \mathrm{C}$ was compared to that of trout acclimated at $22^{\circ} \mathrm{C}$ over a $15-\mathrm{min}$ exposure to each of four thermal environments $\left(12^{\circ}, 17^{\circ}, 22^{\circ}\right.$, and $\left.27^{\circ} \mathrm{C}\right)$. Activity increased with increases in environmental temperature, and trout acclimated at $12^{\circ} \mathrm{C}$ were significantly more active than those acclimated at $22^{\circ} \mathrm{C}$. The results suggested that increases in environmental temperature may be aversive and that subsequent activity due to thermal increases may be part of an avoidance or escape mechanism.

The water quality of most natural rivers and lakes has been altered by reservoirs, storages, releases, diversion, and other multiple water-use developments. For example, reservoirs have their primary effect on water quality by reducing turbidity and water temperature. Such changes in stream ecosystems have a major effect upon aquatic animal and plant life (Friedman, 1969). Aquatic poikilotherms, such as fish, are able to adapt to thermal increases in their environment for short periods of time through physiological changes, such as increased metabolic activity (Fry, 1947). Fish are able to extend their temperature tolerance through the process of acclimation (Brett, 1956). Fisher \& Elson (1950) have demonstrated that the distance traveled in response to an electrical stimulus in Salmo salar and Salvelinus frontinalis is a function of the environmental temperature and the strength of the stimulus. This suggests that temperature has an effect upon fish activity. The present investigation was designed to assess the effects of varying environmental temperatures and levels of acclimation upon the behavioral activity of rainbow trout. SUBJECTS

The Ss were 32 rainbow trout (Salmo gairdneri) obtained from a local hatchery 1 to 3 weeks prior to experimentation. Within the laboratory the Ss were maintained in groups of 2 in 19-liter acquariums at either $12^{\circ} \mathrm{C}$ or $22^{\circ} \mathrm{C}$. The Ss ranged in weight from 2 to $3 \mathrm{~g}$ and were $3.4 \mathrm{~cm}$ long.

\section{APPARATUS}

The experimental apparatus is schematized in Fig. 1. The apparatus consisted of a gray plywood chamber, $30 \mathrm{~cm}$ long, $15 \mathrm{~cm}$ wide, and $20 \mathrm{~cm}$ high. A gray plywood partition divided the chamber into two equal compartments. A series of $6 \cdot \mathrm{mm}$ holes perforated the partition, permitting an easy flow of water. A $5 \cdot \mathrm{cm}$ aperture extending the width of the partition, $6.25 \mathrm{~cm}$ from the bottom, permitted free movement of the $S$ from one compartment to the other. Infrared photoelectric cells were mounted parallel to the aperture outside the chamber. If movement was made in either direction through the aperture, the photoelectric beam would be broken, activating an electronic counter.

A perforated rubber hose, $1.25 \mathrm{~cm}$ in diam, was attached to a water source and transversed the bottom of the chamber. A flow of tap water of the desired temperature could be directed through the hose into the chamber. Overflows positioned in one end of the chamber maintained a water level of $17.5 \mathrm{~cm}$.

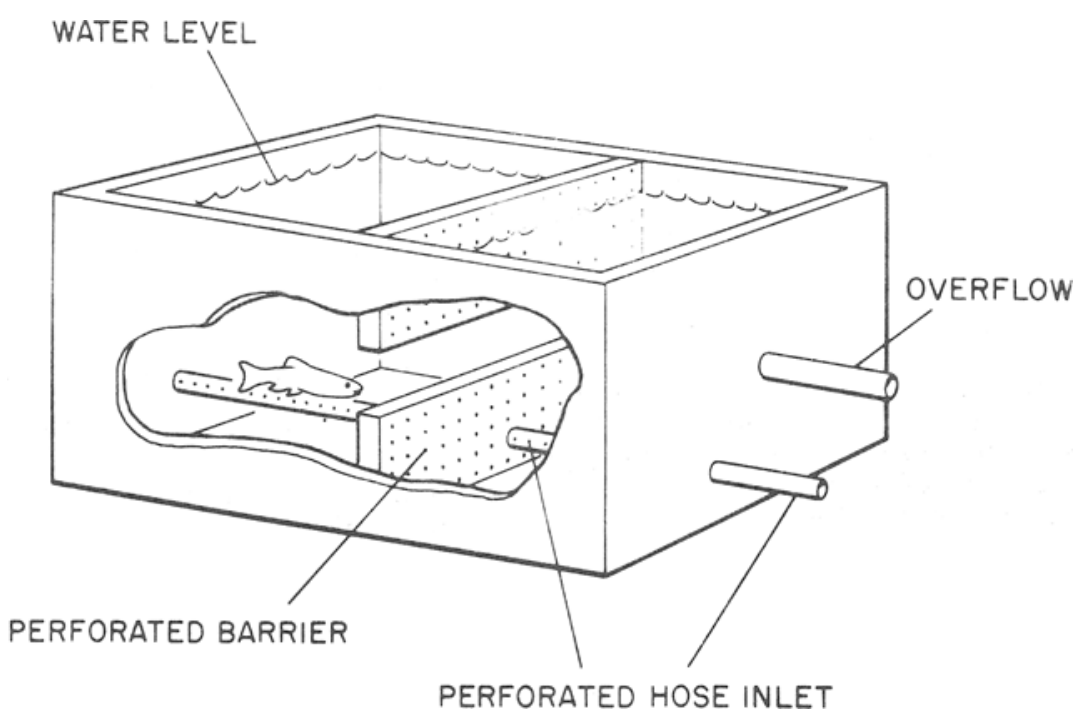

Fig. 1. A schematic of the experimental chamber.

RESULTS AND DISCUSSION

\section{PROCEDURE AND}

EXPERIMENTAL DESIGN

The Ss were acclimated for 1 week at either $12^{\circ} \mathrm{C}$ or $22^{\circ} \mathrm{C}$, with 16 trout within each condition. During testing, all Ss were exposed to each of four thermal conditions $\left(12^{\circ}, 17^{\circ}, 22^{\circ}\right.$, and $27^{\circ} \mathrm{C}$ ) within the test chamber. Eight Ss, 4 from each acclimation level, were exposed to each of four orders of presentation ( 4 by 4 Latin square).

All Ss were tested individually. At the beginning of each session, the $S$ was placed in the apparatus for a period of $15 \mathrm{~min}$. At the end of the time interval, the $S$ was removed from the chamber and placed in a Pyrex jar containing $250 \mathrm{ml}$ of $12^{\circ} \mathrm{C}$ or $22^{\circ} \mathrm{C}$ water (same as acclimation level) for a period of $15 \mathrm{~min}$ At the end of the 15-min intertrial interval (ITI), the S was again placed in the apparatus at a new temperature setting. In this manner, all Ss were exposed to each of the four temperature variations for a period of $15 \mathrm{~min}$ each, with a $15-\mathrm{min}$ ITI between each setting. The number of movements through the aperture were recorded for each session.

Figure 2 presents the mean frequencies of responses for the two groups acclimated at $12^{\circ} \mathrm{C}$ and $22^{\circ} \mathrm{C}$ over the four test temperatures. The analysis of variance (Lindquist, Type IV, 1953) yielded a significant difference between the acclimation levels $(F=32.38, \mathrm{df}=1 / 24, p<.01)$, within temperature levels $(F=68.13$, $d f=3 / 72, \quad p<.01)$ and a Temperature by Acclimation interaction $(F=26.38, \quad d f=3 / 72$, $\mathrm{p}<.01)$. All other effects were nonsignificant $(p>.01)$. Multiple comparisons were made using the Duncan multiple-range test. Ss 


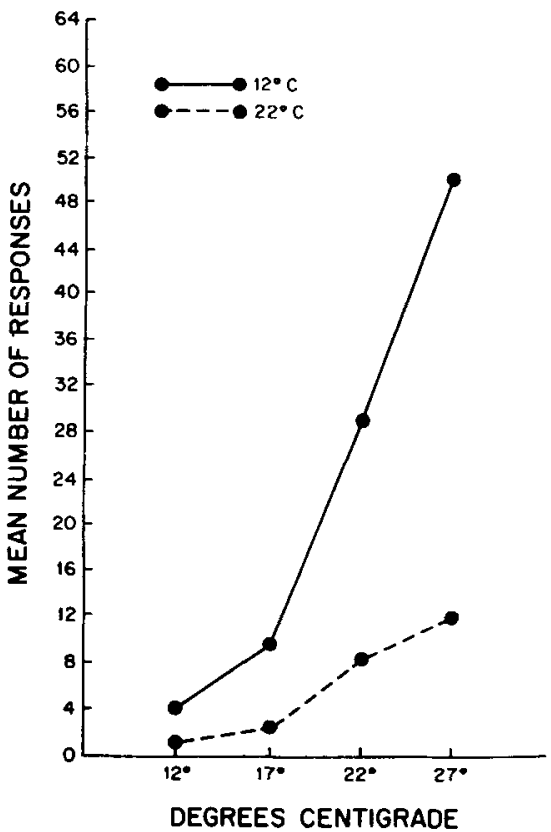

Fig. 2. Changes in activity as a function of temperature for Ss differing in levels of acclimation. acclimated at $12^{\circ} \mathrm{C}$ showed a significant difference at all levels $(\mathrm{p}<.01)$ except under the $12^{\circ} \mathrm{C}$ and $17^{\circ} \mathrm{C}$ conditions. Significant differences were also obtained between the $12^{\circ} \mathrm{C}$ and $22^{\circ} \mathrm{C}$ acclimation levels, with the exception of the $12^{\circ} \mathrm{C}$ and $17^{\circ} \mathrm{C}$ test temperatures. All other comparisons were nonsignificant $(p>.01)$.

The results of the present study indicate that activity is a function of water temperature. As can be observed in Fig. 2, activity in trout acclimated at $12^{\circ} \mathrm{C}$ increased with increases in test temperature, whereas trout acclimated -at $22^{\circ} \mathrm{C}$ were significantly less active at the $22^{\circ} \mathrm{C}$ and $27^{\circ} \mathrm{C}$ test temperatures. Similarly, fish acclimated at low temperatures have lower metabolic and tolerance levels than conspecifics acclimated at a higher temperature (Brett, 1956). This suggests that the more divergent the temperature from the acclimation level, the more aversive it becomes. Homeotherms, such as rats, will barpress to escape aversive thermal conditions (Epstein \& Milestone, 1968). The activity functions in the present research may be one aspect of an avoidance or escape behavior pattern.

\section{REFERENCES}

BRETT, J. R. Some principles in the thermal requirements of fishes. The Quarterly Review of Biology, 1956, 31, 75-87.

EPSTEIN, A. N., \& MILESTONE, $R$ Showering as a coolant for rats exposed to heat. Science, 1968, 160, 895-896.

FISHER, K. C. \& ELSON, P. F. The selected temperature of Atlantic salmon and speckled trout and the effect of temperature on the response to an electrical stimulus. Physiological Zoology. $1950,23,27-34$

FRIEDMAN, $S$. Thermal addition: One step from thermal pollution. Bioscience, 1969, $19,60-61$.

FRY, F. E. J. Effects of the environment on animal activity. Publications of Ontario Fish Research Laboratory, 1947. No. 55 Cited by W. S. Hoar, General and comparitive physiology. New Jersey: Prentice-Hall, 1966. P. 313.

LINDQUIST, E. F. Design and analysis of experiments in psychology and education. Boston: Houghton-Mifflin. 1953.

\section{ERRATUM}

Several errors in page numbers appear on the cover of Volume 21, Number 5 . The following corrections should be made.

\begin{tabular}{cc} 
Was & Should be \\
\cline { 2 - 2 } $280-296$ & $280-292$ \\
299 & 293 \\
304 & 300 \\
310 & 306 \\
238 & 258 \\
314 & 310 \\
320 & 316 \\
300 & 296 \\
302 & 298 \\
312 & 308 \\
298 & 294 \\
306 & 302 \\
308 & 304 \\
317 & 313 \\
318 & 314
\end{tabular}

Similar errors were made in the table of contents of Volume 21. They may be corrected by locating the beginning of a title and changing the page numbers as follows:
Under Motivation-

An expression of body weight ... 299 should be 293 300

Prey selection... 304 should be

Sex differences ... 310 should be 306

Under Learning-

The classically conditioned . . . 300 should be 296

Generalization gradients ... 302 should be 298 308

Reversal learning . . . 312 should be

Under Avoidance and Punishment-

Between-groups incentive... 298 should be 294

The buzzer ... 306 should be 302 304

Shock-avoidance ... 308 should be

Effects of a punitive . . 317 should be 313

Motivation-performance . . . 318 should be 314
Under Social Behavior-

Social inhibition ... 314 should be 310

Dependence . . 320 should be 316

The same errors appeared in the author index and should be corrected as follows:

Anderson, W. H., 298; Ayres, J. J. B., 294; Booth, D. A., 293 (from 209); Campbell, H. W., 300; Crawford, M. L. J., 304; Forman, H., 316; Harris, C. J., 316 (from 320); Henderson, N. D., 314; Hogan, J., 316; Johnson, D. F., 298; Levinthal, C. F., 296; Matyniak, K. A., 308; Melvin, K. B., 313; Morrison, B. J., 316 (from 320); Nyby, J., 310; Papsdorf, J. D., 296; Quinsey, V. L., 294; Riess, D., 302 (from 306); Rollings, J. P., 313; Singh, D., 306; Stettner, L. J., 308; Thiessen, D. D., 310; Wallace, P., 310.

The person who made these errors is no longer on our staff.

Editor 